\title{
EFL students' achievement and attitudes towards flipped pronunciation class: correlational study
}

Wagdi Rashad Ali Bin-Hady

Department of English Language, Hadhramout University, Socotra, Yemen, and

\author{
Abduljalil Nasr Hazaea \\ Department of English Language, Najran University, Najran, Saudi Arabia and \\ Sana' a University, Sana'a, Yemen
}

EFL students' achievement and attitudes

\begin{abstract}
Purpose - Existing research has examined English as a foreign language (EFL) students' attitudes towards flipped learning. However, no study seems to have correlated students' achievement and their attitudes towards flipped learning. Yemeni EFL students also face pronunciation problems and they lack technologyenhanced language learning. The flipped learning approach promotes active learning and increases students' learning outcomes. This study aims to measure the achievement level and the attitudes of Yemeni EFL students towards flipped pronunciation classrooms. It also correlates between achievement and attitudes towards this new experience.
\end{abstract}

Design/methodology/approach - Using a correlational research design, quantitative and qualitative data were collected through a test, questionnaire and structured interview from an intact class of Yemeni EFL students at the College of Education in Socotra.

Findings - The one-sample $t$-test analysis shows that the respondents scored high in the achievement test. The analysis of both the questionnaire and the structured interview revealed that the students have a positive attitude towards the flipped pronunciation classroom. The correlation analysis indicated a high-level positive relationship between students' achievement and their attitudes where $r=0.779$ with $p<0.001$, two-tailed.

Research limitations/implications - The present study has some limitations regarding the sample size. This context-specific study recruited the available EFL class at the College of Education in Socotra, Hadhramout University. It would be more reliable should the study compared large groups of students so that the results can be generalized.

Practical implications - The study recommends using flipped learning to enhance pronunciation among EFL students.

Originality/value - This study contributes to the correlational studies in flipped learning.

Keywords EFL students, Achievement, Attitude, Pronunciation, Flipped classroom, Correlational design

Paper type Research paper

(C) Wagdi Rashad Ali Bin-Hady and Abduljalil Nasr Hazaea. Published in PSU Research Review. Published by Emerald Publishing Limited. This article is published under the Creative Commons Attribution (CC BY 4.0) licence. Anyone may reproduce, distribute, translate and create derivative works of this article (for both commercial and non-commercial purposes), subject to full attribution to the original publication and authors. The full terms of this licence maybe seen at http:// creativecommons.org/licences/by/4.0/legalcode

Received 28September 2020 Revised 27 November 2020 9 December 2020 Accepted 14 December 2020 


\section{PRR}

6,3

\section{Introduction}

Flipped learning has brought the attention of English language teachers and researchers to student-centred and technology-enhanced approaches. Choe and Seong (2016) stressed the importance of flipped learning in English as a foreign language (EFL) contexts. Flipped learning was applied in different EFL skills. Some studies used flipped learning on grammar (Al-Harbi and Alshumaimeri, 2016; Singay, 2020b); on pronunciation (Yang and Chen, 2020; Zhang et al., 2016); on listening (Ahmad, 2016; Vaezi et al., 2019); on writing (Ahmed, 2016; Alghasab, 2020; Arslan, 2020); on reading (Karimi and Hamzavi, 2017); and on speaking (Abdullah et al., 2019; Arslan, 2020; Köroğlu and Çakır, 2017). Other flipped EFL classes were conducted in Saudi Arabia (Ahmed, 2016; Al-Harbi and Alshumaimeri, 2016) in Egypt (Ahmad, 2016), in Iran (Yousefzadeh and Salimi, 2015) and among Bhutanese students (Singay, 2020b). So far, no flipped study was reported from the Yemeni EFL context with any language skill.

Studies on the flipped learning put a focus either on assessing students' attitudes towards using the flipped learning (Maharani et al., 2020; Singay, 2020b) or on improving language skills (Ahmed, 2016; Obari and Lambacher, 2015; Singay, 2020a). Flipped learning is found to improve EFL language skills specially oral skills. Al-Maroof and Al-Emran (2020) reported that flipped EFL learning achieved positive outcomes in China, Turkey, Taiwan and Malaysia. To the best of the researchers' knowledge, it seems no study has examined the relationship between EFL students' achievement and attitudes in a flipped classroom.

Previous research also shows that Arab EFL learners face problems in acquiring English vowel and consonant sounds (Al-Ahdal et al., 2015; Altamimi, 2015; Bin-Hady, 2016b, 2016c; Jalabneh, 2014). For example, Altamimi (2015) reported mispronunciation of five consonant phonemes (/p/,/3/,/v/,/t//and/y/) with Arab EFL learners. Bin-Hady (2016b) found that some Yemeni EFL school students traditionally repeat the English sounds after their teachers without basic use of technology-enhanced language learning.

As university lecturers, the researchers observed that first-year students join English language programmes with very poor knowledge of the English sound systems either in terms of pronouncing or transcribing single words. Even motivated and good students usually perform weakly in the pronunciation course. At the cutting edge of communication technology, Yemeni EFL students are still confined to traditional learning approaches without getting much benefit from technology for learning. Therefore, there is a need to make use of the internet and technology which can help students in improving their pronunciation. One way is to flip pronunciation traditional classes. It is hypothesized that the respondents will improve correct pronunciation, enjoy flipped learning. It is also hypothesized that there will be a strong positive relationship between students' achievement and attitudes towards the pronunciation flipped class.

After highlighting the context, scope and problem addressed in this study, the following five sections outline the report of this paper. The review of literature presents flipped learning, its advantages and disadvantages, the role of technology-enhanced learning on pronunciation. It also shows the existing gaps in achievement and attitudes towards flipped learning. The research objectives are then introduced. The method section illustrates the correlational research design. It also shows how the test, structured interview and questionnaire were collected and analysed. The results are discussed in line with the research objectives. The study concludes with the main findings, limitations and recommendations for further research. 


\section{Literature review}

Flipped learning

A flipped class is defined as the provision of "pre-assigned learning materials that students usually use before class (e.g. by watching a lecture video) and applying the instructional material during class (e.g. by working on problem-solving assignments)" (Van Alten et al., 2019, pp. 1-2). Jurmey et al. (2019) stated that in the flipped class students are required to do some tasks at home before the class such as watching videos, thereby better preparing themselves for class. The same authors believed that the flipped class not only aims to achievement and attitudes engage students but also to improve their achievement.

Flipped learning has its advantages and disadvantages. On the one hand, flipped learning has some positive characteristics including "free classroom time, opportunities for personalized learning, opportunities for more student-centred learning, a continuous connection between student and teacher, the increased motivation of students" (Basal, 2015, p. 34). Similarly, flipped learning is thought to benefit students increase their active learning and enjoyment (Soler et al., 2018). On the other hand, Arslan (2020) found out that the internet access and disconnection as a challenge for students in some flipped learning classes. Bakla (2018) revealed that students face some difficulties in this kind of learning as they are accustomed to use traditional modes of teaching. Similarly, Zainuddin et al. (2019) reported the instructors' inability to motivate students to watch the videos before the class. Even though flipped learning has gained popularity as a research area, Doman (2017) called for conducting further research on its use in language learning.

\section{Flipped learning and students' achievement}

Does flip learning enhance EFL students' pronunciation? Two studies were reported from the Chinese EFL context. Zhang et al. (2016) studied the effectiveness of flipped pronunciation classrooms on the performance of Chinese EFL students. The study compared students' final pronunciation scores taught in the flipped classroom with other students' final scores taught traditionally. The study revealed that students who implemented flipped learning outperformed higher than students who traditionally taught. Yang and Chen (2020) investigated the Chinese EFL students' achievement and students' and teachers' attitudes towards flipped classes of English vowel letters. Using an experimental research design, the study found that both primary students and their teachers generally prefer those flipped classes. The students also scored higher in the flipped classes. These studies showed the potential of using flipped learning to improve pronunciation skills among EFL students.

In other language skills, several studies focused on flipped learning and learning outcomes in EFL classrooms (Webb and Doman, 2016; Yousefzadeh and Salimi, 2015). For example, Webb and Doman (2016) studied the effect of flipped learning on Chinese students' outcomes in grammar. They took the control group and the experimental group. Though both groups reported self-comfort, the experimental group got higher outcomes. Likewise, Yousefzadeh and Salimi (2015) investigated the efficacy of flipped learning on Iranian students. They recruited 10 teachers each one taught two classes, in which one is taught traditionally and the second is flipped. They performed pre and post-tests. They found significant differences between the outcomes of the two groups for the experimental group students.

\section{Flipped learning and students' attitude}

Several studies reported positive impact that students have after being flipped on grammar (Al-Harbi and Alshumaimeri, 2016; Singay, 2020b); on pronunciation (Zhang et al., 2016); on 
PRR

6,3

listening (Ahmad, 2016; Vaezi et al., 2019); on writing (Ahmed, 2016; Alghasab, 2020); on reading (Karimi and Hamzavi, 2017); and speaking (Köroğlu and Çakır, 2017).

Singay (2020b) studied Bhutanese students' attitude towards flipping grammar class. His study reported that students learned English grammar better and showed good attitudes and perceptions towards flipped classroom learning. Karimi and Hamzavi (2017) also studied the efficacy of flipped learning on Iranian EFL learners in reading comprehension. Controlled and experimental groups were pursued and tested at the beginning of the course. The experimental group was flipped while the controlled group was traditionally taught. The experimental group outperformed the controlled group and got positive attitudes towards flipped learning. Obari and Lambacher (2015) conducted two case studies in the Japanese context for both the control and experimental group. They conducted pre and posttests on both groups for the Test of English for International Communication (TOEIC). They found that the experimental group outperformed the control group.

In the EFL Arabic context, moreover, Ahmad (2016) studied the effect of a flipping classroom on Egyptian EFL students listening comprehension. The study-oriented one group pre and post-tests in listening compression and between them went the intervention, i.e. the implementation of flipped learning. The findings revealed a significant difference in the main scores in favour of the post-test. Still in the Arabic context, Ahmed (2016)explored the significance of flipped learning in the writing skill of Saudi EFL students. The study recruited control and experimental groups. Both groups were pre-tested and the experimental group was taught using a flipped classroom while the controlled group was taught traditionally. The groups were post-tested in writing. The finding showed that the experimental group performed better than the controlled group. Moreover, the experimental group scored higher in their attitudes towards a flipped classroom than their scores at the beginning of the course. Al-Harbi and Alshumaimeri (2016) investigated the effect of flipping learning on Saudi secondary school grammar. However, they found that the experimental group outperformed the control group, the mean scores of the experimental group was not statistically significant.

Studies on flipped learning-focused either on experimental research designs (Ahmed, 2016; Obari and Lambacher, 2015; Singay, 2020a) or on assessing students' attitudes towards using the flipped learning (Maharani et al., 2020; Sunday, 2020b). Ashwin and Mcvitty (2015, p. 345) stated that "engagement can help students to improve their learning outcomes". This statement indicates the need to examine the relationship between students' attitude and their achievement in a flipped pronunciation classroom. It seems no study has examined the relationship between EFL students' achievement and attitudes in a flipped pronunciation class.

Subsequently, this article contributes to the existing literature on the use of flipped EFL pronunciation. Firstly, it adds to the literature on the flipped classroom being viable globally. It examines the unanswered question about the relationship between EFL students' achievement and their attitudes towards flipped pronunciation class. Secondly, to the best of the researchers' knowledge, no research has addressed EFL students' achievement and attitudes towards the flipped pronunciation class in the Yemeni context.

\section{Research objectives}

This study measures the Yemeni EFL students' achievement, attitudes and the relationship between achievement and attitudes towards the flipped pronunciation class. Using a correlational research design, the study aims to achieve the following research objectives:

- to measure the achievement level of Yemeni EFL students in the pronunciation flipped classroom; 
- to examine the attitudes of Yemeni EFL students towards the flipped pronunciation class; and

- to correlate between Yemeni EFL students' achievement and their attitudes towards the flipped pronunciation class.

EFL students' achievement and attitudes

\section{Method}

This study uses a correlational research design (Figure 1) to examine the relationship between EFL students' achievement and their attitudes towards the flipped learning method in an intact pronunciation class.

Correlation design is defined as "procedures in quantitative research in which investigators measure the degree of association (or relation) between two or more variables using the statistical procedure of correlational analysis" (Creswell, 2012, p. 21).

\section{Settings and respondents}

Every year around 40 students join the department of English language in the College of Education Socotra, Hadhramout University. Most students live in Socotra, a Yemeni island and governorate in the Arabian sea. The researchers selected the available intact pronunciation class of 22 students (10 men and 12 women) in the first semester of (20192020). The students ranged in age between 18 and 21 years old. The English language is considered a foreign language for them.

Pronunciation is a 3 - $h$ credited course in the English language programme. The course uses 'A Tree or Three? Elementary Pronunciation Textbook' written by Ann Baker (2009). Although the course is designed to be taught theoretically and practically, it is used to be conducted theoretically because of the absence of the language lab. The first researcher observed that these students, either men or women, used their smartphones in the corridors and outside the classroom for communication, accessing such social media networks as Facebook and WhatsApp. However, YouTube is rarely used because of the slow internet connection. This practice indicates both a waste of time and loss of the practical part of the course without technology-enhanced pronunciation learning.

The flipped pronunciation class tries to move the stagnant waters on traditional teaching of pronunciation by sharing selected videos and audio to students which allows them to practice at home as many times as they need. It is hoped that students will acquire the correct pronunciation recorded by native speakers and will be able to participate more confidently in the class as they develop their pronunciation skills.

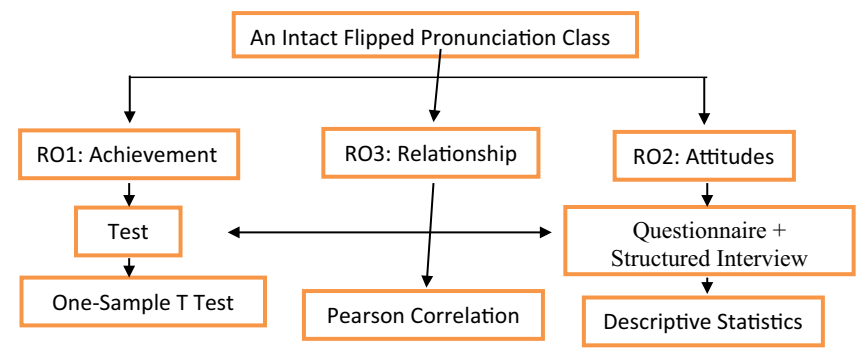

Figure 1. Correlational research design 


\section{PRR}

6,3

180

\section{Instruments}

Three instruments were used in this study: the pronunciation performance test, the questionnaire and the structured interview.

Performance oral and written test was used to measure the respondents' achievement. The broad objective of the course is to equip students with theoretical and practical knowledge in the pronunciation of English words and sentences. The course aimed to achieve certain objectives including enhancing students' theoretical knowledge, and also fluency in English pronunciation. The performance test was prepared in line with the course learning outcomes (Table 1) and validated by two experts in the field. Based on their suggestions, the test was improved.

The questionnaire (Appendix 1) was adapted from Jurmey et al. (2019). The original questionnaire was a general questionnaire which measured students' attitudes on using flipped classroom in different subjects. The questionnaire consisted of two parts. In the first part, the demographic information of the respondents was collected. Such information included name (optional), age and gender. The second part involved 20 items about the students' attitudes towards the flipped pronunciation class. A five-point Likert scale was used ranging from strongly agree (5) to strongly disagree (1). The questionnaire was also checked for reliability through statistical analysis resulting in a Cronbach's alpha based on standardized items of 0.809 , thus indicating that the questionnaire was reliable for data collection.

To triangulate the evidence from the questionnaire data, the structured interview (Appendix 2) was conducted by randomly selecting half of the respondents ( 5 men) and (6 women). The structured interview consisted of nine questions. The interview data were recorded using an mp3 recorder. Five short questions were analysed statistically and four WH questions were analysed thematically.

\section{Procedures for data analysis}

This study is quantitative in nature and the three tools were analysed using SPSS (version 22). The qualitative part of the structured interview was analysed thematically. To answer the first research objective, the test was analysed using a one-sample $t$-test analysis to get the means and standard deviations. In line with the university achievement policy, the test value of (2.5) was used as the theoretical mean. In total, 95\% is also used as the confidence interval of the difference.

The second research objective was answered using the questionnaire and the structured interview. The questionnaire was analysed using descriptive analysis to generate the mean scores and standard deviations of the positive and the negative statements of the questionnaire. Similarly, the quantitative part of the structured interview was described using frequency and percentage. The qualitative part was analysed thematically through a

\begin{tabular}{lll}
\hline Learning outcomes (LOs) & Teaching strategy & Assessment \\
\hline $\begin{array}{l}\text { LO1: Demonstrate basic theoretical knowledge } \\
\text { in English pronunciation }\end{array}$ & Flipped learning & Oral and written test \\
$\begin{array}{l}\text { LO2: Identify vowel sounds of different English } \\
\text { simple words }\end{array}$ & Flipped learning & Oral and written test \\
$\begin{array}{l}\text { LO3: Use the pronunciation of consonant } \\
\text { phonemes with more focus on the phonemes not } \\
\text { found in the Arabic language }\end{array}$ & Flipped learning & Oral and written test \\
$\begin{array}{l}\text { LO4: Distinguish between the pronunciation of } \\
\text { English minimal pairs }\end{array}$ & Flipped learning & Oral and written test \\
LO5: Pronounce isolated sounds and short & Flipped learning & Oral and written test \\
\hline English sentences & &
\end{tabular}

Table 1.

Matrix for the course assessment 
close reading of the collected data. To present systematic analysis, a coding system was used (SSn) where SS stands for (student) and $n$ stands for (number of the student).

The third research objective was answered statistically. Pearson's correlational framework is used. It reveals three types of relationships. It reports a strong, low or week positive relationship at +1 or negative relationship at -1 and neutral relationship at 0 . Correlation is significant at the 0.01 level (two-tailed).

\section{Results and discussion}

This section reports the results and discussion. It is presented in line with the research objectives.

\section{Students' achievement in the flipped pronunciation class}

This study first aimed to measure EFL students' achievement in the flipped pronunciation class. The respondents' overall achievement scores were analysed. The overall result of the intact class is high with a mean score of 3.61 and a standard deviation of 0.47975 . The variations in the scores reflect the heterogeneous nature of the available intact class. The one-sample $t$-test shows a "high" achievement test of the intact class (Table 2).

Table 2 shows the differences between the theoretical mean (2.5) and the overall mean (3.6) of achievement. All in all, the one-sample $t$-test revealed a mean difference of (1.110) where the upper difference is (1.32) and the lower difference is (0.89) at 95\% confidence interval of the difference where sig. (two-tailed) equals (0.000). This analysis showed that the respondents obtained a "high" score in the achievement test of the pronunciation class. This finding coincides with previous research. Yang and Chen (2020) and Zhang et al. (2016) found that students in flipped pronunciation outperformed higher than those who were traditionally taught. Webb and Doman (2016) reported that the experimental group in flipped grammar among Chinese EFL students got higher outcomes. Likewise, Yousefzadeh and Salimi (2015) found significant differences in the learning outcomes among Iranian EFL students in a flipped classroom.

\section{Students' attitudes towards flipped pronunciation class}

The second research objective set in this study was to examine Yemeni EFL students' attitudes towards the flipped pronunciation class. To achieve this objective, respondents' attitudes were elicited from both the questionnaire and the structured interview.

Table 3 shows students' responses to the questionnaire items with an overall total mean score of 4.1046 and a standard deviation of 0.971976 . The respondents responded with strong

\begin{tabular}{|c|c|c|c|c|c|c|c|}
\hline \multirow[b]{2}{*}{ Intact class } & \multirow[b]{2}{*}{$t$} & \multirow[b]{2}{*}{ df } & \multirow{2}{*}{$\begin{array}{c}\text { Sig. } \\
\text { (two-tailed) }\end{array}$} & \multirow{2}{*}{$\begin{array}{c}\text { Mean } \\
\text { difference }\end{array}$} & \multicolumn{2}{|c|}{$\begin{array}{l}95 \% \text { confidence interval } \\
\text { of the difference }\end{array}$} & \multirow{3}{*}{$\begin{array}{r}\text { Table } 2 . \\
\text { One-sample test }\end{array}$} \\
\hline & & & & & Lower & Upper & \\
\hline Achievement test & 10.857 & 21 & 0.000 & 1.11045 & 0.8977 & 1.3232 & \\
\hline \multicolumn{4}{|c|}{ Attitudes towards the flipped pronunciation class } & Mean & & $\mathrm{SD}$ & \multirow{2}{*}{$\begin{array}{r}\text { Table } 3 . \\
\text { Participants' } \\
\text { attitudes towards the } \\
\text { flipped pronunciation } \\
\text { class }\end{array}$} \\
\hline \multicolumn{3}{|c|}{$\begin{array}{l}\text { Positive statements } \\
\text { Negative statements } \\
\text { Total }\end{array}$} & & $\begin{array}{l}4.097 \\
4.136 \\
4.106\end{array}$ & & $\begin{array}{l}0.950061 \\
1.059635 \\
0.971976\end{array}$ & \\
\hline
\end{tabular}

EFL students' achievement and attitudes

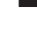


PRR

6,3

182

disagreement to the negative statements with a total mean score of 4.136, and a standard deviation of 1.059635. These scores mean a high-level positive attitude towards the flipped learning.

The analysis of the structured interview also reported positive attitudes towards the flipped pronunciation class (Table 4).

Table 4 shows that $90.90 \%$ of the interviewees got enough time to practice sounds. In total, $100 \%$ of the respondents reported that they had enough time to practice sounds with their friends and that they preferred to study other courses in the flipped approach. Moreover, $63.63 \%$ said that they understood better in the flipped class than in the traditional one.

In responding to the open questions of the interview, the respondents showed a positive attitude towards the flipped pronunciation class as is evident in the following excerpt:

I think it [flipped pronunciation class] is wonderful (SS4); it is good (SS11); it is easy when you prepare at home (SS9); it is very good and exciting (SS3); it is very good (SS2); it is good for us (SS1); it is a very good way (SS7); it is very good (SS10); it is very good (SS5); it is very good for us (SS6); good (SS8)

The respondents reported their interests and excitement when they come to the lecture prepared as it is evident in the following excerpt:

Interested in the lecture (SS3); I know before, interesting (SS1); excited (SS9); excited (SS7); good (SS2); I feel that I can understand (SS4); very good (SS11); I get ready and the lecture becomes interesting (SS5); comfortable and interesting (SS10); interested in the lecture (SS6); it is good for me (SS8).

Moreover, the respondents showed that both videos and recordings are better sources to learn more about pronunciation as is evident in the following excerpt:

Video and recording (SS4); video (SS2); video and recording (SS6); in the class (SS11); both (SS1); both (SS3); video and recording (SS9); videos (SS5); all of them (SS7); both (SS8); both (SS10)

Also, the respondents found that the flipped pronunciation class was a powerful tool for preparing for the lesson and practicing as many times as they wished and provided better understanding compared with the traditional classes. The following excerpt shows their responses:

[... .] it is good to know before you come to college (SS3); you can prepare at home (SS5); it is good to prepare at home (SS8); it is good for us to prepare (SS1); I can practice at home many times (SS11); it is good when we don't have enough time in the classroom (SS6); it is interesting to practice words, phrases (SS2); when I study at home (SS4), I understand better in the class (SS7).

Although six respondents reported that they did not see weaknesses in the flipped learning, five respondents reported that they faced technical problems, the complexity of the sounds of the English language, as well as the issue of American and British accents as it was evident in the following excerpt:

\begin{tabular}{|c|c|c|c|c|}
\hline \multirow[b]{2}{*}{ Question } & \multicolumn{2}{|c|}{ Yes } & \multicolumn{2}{|c|}{ No } \\
\hline & FREQ & $(\%)$ & FREQ & $(\%)$ \\
\hline $\begin{array}{l}\text { Have you ever studied the sounds before coming to } \\
\text { university? }\end{array}$ & 2 & 18.18 & 9 & 81.81 \\
\hline Do you get enough time to practice pronunciation or not? & 10 & 90.90 & 1 & 9.09 \\
\hline $\begin{array}{l}\text { Do you understand better this teaching method or do you } \\
\text { want to study by traditional learning? }\end{array}$ & 7 & 63.63 & 4 & 36.37 \\
\hline $\begin{array}{l}\text { Do you have enough time to practice English with your } \\
\text { colleague in the flipped class? }\end{array}$ & 11 & 100 & 0 & 0 \\
\hline $\begin{array}{l}\text { Do you want to study other courses in the same way as } \\
\text { pronunciation? }\end{array}$ & 11 & 100 & 0 & 0 \\
\hline
\end{tabular}

Table 4.

Participants' responses to the interview regarding the flipped pronunciation class

pronunciation? 
Some technical problems (SS4); the bad thing is a lot of sounds (SS9) some videos have different American and British English (SS6); I don't understand some vowels because they are difficult (SS3).

All in all, the respondents who engaged in the treatment, expressed their interest and motivation in this new experience. They further recommended it for other language skills. The respondents had a positive attitude towards the flipped pronunciation class with a mean score of 4.1045 and a standard deviation of 0.50519. Similarly, students also reported a positive attitude towards pronunciation class in their responses to the interview. Some of the students' opinions were "I think it is wonderful; it is good; it is easy when you prepare at home". This finding is in line with previous research (Ahmed, 2016; Karimi and Hamzavi, 2017) in which it was reported that students showed a positive attitude in the experimental group that differs significantly from that of their peers who were traditionally taught both reading and writing skills. Singay (2020b) also found that the flipped class had a good impact on Bhutanese students' attitudes in learning grammar. The results of our study also coincided with Ahmad (2016) in which she found that Egyptian students who were taught in the flipped class outperformed their peers taught in traditional classrooms in listening comprehension. This finding confirms the necessity to integrate the flipped method of learning in the Yemeni context to update Yemeni undergraduates with advanced technology and lifelong learning. As the study reported, only two students complained about the large number of vowel sounds they hand to learn and nine students reported that they have never studied English sounds before college. There is a call for integrating English vowel sounds in high schools' curriculum. This is confirmed by Bin-Hady (2016a) that phonology was missed in the Yemeni secondary school English classroom.

\section{Correlation between students' achievement and attitudes}

The third research objective was to correlate students' achievement and their attitudes towards the flipped pronunciation class. The correlational analysis measured the direction and the strength of the linear association between students' attitudes and their achievement. The $t$-test analysis shows that mean of attitudes was 4.10 and the standard deviation was 0.50519 . As for the achievement test, the mean score was 3.611 and the standard deviation was 0.47975 (Table 5).

Table 5 reports the overall correlation result between students' attitudes and their achievement. It indicated that students' attitudes towards the flipped pronunciation class were positively and highly correlated with achievement $(r=0.78, p<0.001$, two-tailed). This $\mathrm{R}$-value indicates a strong positive linear relationship via a firm linear rule.

As can be seen in Figure 2, four values were associated with the line. Most of the values are close to the line. Only one value appears to be far from the line. This value represented

\begin{tabular}{lcc}
\hline Pearson correlation & Attitudes & Achievement \\
\hline $\begin{array}{l}\text { Attitudes } \\
\text { Pearson correlation }\end{array}$ & 1 & $0.779^{* * *}$ \\
$\begin{array}{l}\text { Sig. (two-tailed) } \\
n\end{array}$ & 22 & 0.000 \\
Achievement test & $0.779^{* *}$ & 22 \\
Pearson correlation & 0.000 & 1 \\
Sig. (two-tailed) & 22 & 22 \\
$n$ & & \\
Note: ${ }^{* *}$ Correlation is significant at the 0.01 level (two-tailed) &
\end{tabular}

EFL students' achievement and attitudes

183 


\section{PRR \\ 6,3}

184

Figure 2.

Individual correlation

analysis between

students' attitudes

and their

achievement test

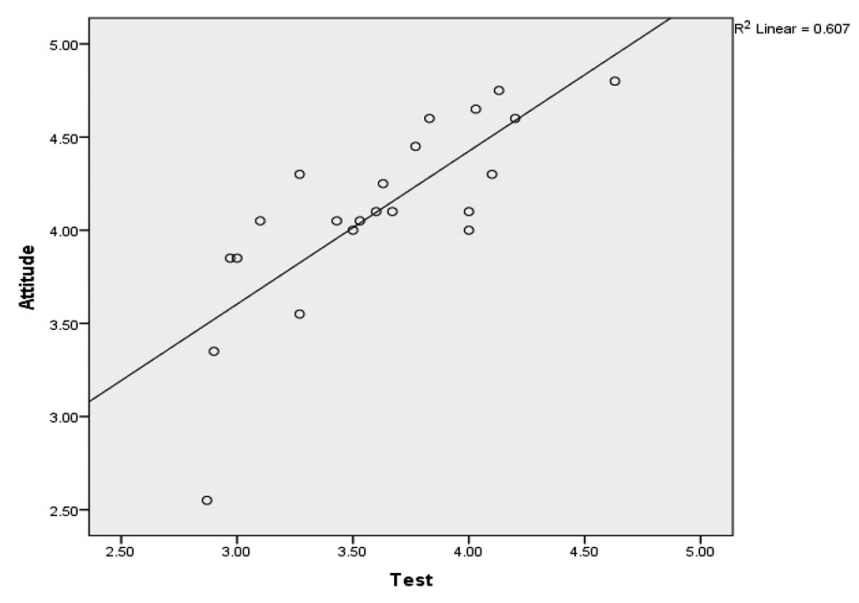

the weakest value. These values represented a positive correlation between students' attitudes and their achievement.

The study found a positive correlation between students' attitudes towards the flipped class and their achievement in the pronunciation course. This finding coincides with Webb and Doman (2016) who found that students in China and the USA who were taught in a flipped grammar class outperformed their peers who were traditionally taught grammar. Likewise, this finding is in line with that of Zhang et al. (2016). They found that the flipped teaching mode showed more effect on students' outcomes in pronunciation than the achievement of students who were traditionally taught. To sum up, this study confirmed the beliefs of Ashwin and Mcvitty (2015) that students' engagement enhanced their achievement. As students can practice the sounds as much as they wish at their home, so can they internalize the sounds better and certainly perform better on the test.

\section{Conclusion}

The present study introduced flipped learning into an EFL pronunciation class of Yemeni students at Socotra, Yemen. The study found that students achieved "high" in their achievement test. They also showed a positive attitude towards the flipped pronunciation learning and they hoped to study other courses using the flipped learning method. Moreover, the study showed high positive correlations between students' attitudes and students' achievement in the pronunciation course. The study also reported some challenges among some students who reported technical problems in their new experience with flipped learning.

The study suggests that EFL instructors should bring enough authentic teaching materials (audio and videos) to the students at the beginning of the semester. For ensuring students' home preparation, the instructor may give them a plan for each lecture, the number of sounds they are going to study, etc. Instructors should take quizzes at the beginning of each lecture so that students will prepare when they are going to appear in front of their peers to explain the sounds.

The present study has some limitations regarding the sample size and research design. The study recruited the available EFL class at the College of Education in Socotra, Hadhramout University. It would be more reliable if the study compared large groups of students so that the results can be generalized. Similar studies on applying a flipped 
learning approach to reading, listening and other language subsystems such as grammar or vocabulary should be studied in the Yemeni context to determine what the impact of such learning would be on students' outcomes. Such studies will also push the field of flipped learning forwards by providing new insights and contributing to existing knowledge. Finally, the language instructors likely need some training on implying flipped classrooms especially in a very poor learning context like Yemen.

\section{References}

Abdullah, M.Y., Hussin, S. and Ismail, K. (2019), "Implementation of flipped classroom model and its effectiveness on English speaking performance", International Journal of Emerging Technologies in Learning (IJET), Vol. 14 No. 9, pp. 130-147.

Ahmad, S.Z. (2016), “The flipped classroom model to develop Egyptian EFL students' listening comprehension", English Language Teaching, Vol. 9 No. 9, pp. 166-178, doi: 10.5539/elt. v9n9p166.

Ahmed, M.A.E.A.S. (2016), "The effect of a flipping classroom on writing skill in English as a foreign language and students' attitude towards flipping”, US-China Foreign Language, Vol. 14 No. 2, pp. 98-114, doi: 10.17265/1539-8080/2016.02.003.

Al-Ahdal, A.A.M.H., Al-Hattami, A.A., Al-Awaid, S.A.A. and Al-Mashaqba, N.J.H. (2015), "Pronunciation for the Arab learners of EFL: planning for better outcomes", English Language Teaching, Vol. 8 No. 10, pp. 100-106, doi: 10.5539/elt.v8n10p100.

Alghasab, M.B. (2020), "Flipping the writing classroom: focusing on the pedagogical benefits and EFL learners' perceptions", English Language Teaching, Vol. 13 No. 4, pp. 28, doi: 10.5539/elt. v13n4p28.

Al-Harbi, S.S. and Alshumaimeri, Y.A. (2016), "The flipped classroom impact in grammar class on EFL Saudi secondary school students' performances and attitudes”, English Language Teaching, Vol. 9 No. 10, pp. 60-80, doi: 10.5539/elt.v9n10p60.

Al-Maroof, R.A. and Al-Emran, M. (2020), "Research trends in flipped classroom: a systematic review", Recent Advances in Intelligent Systems and Smart Applications, Springer, Cham, pp. 253-275.

Altamimi, A.K. (2015), "Improving English pronunciation among Arabic EFL school-age student using minimal pairs", Unpublished M.A. thesis, State University of New York.

Arslan, A. (2020), "A systematic review on flipped learning in teaching English as a foreign or second language", Dil ve Dilbilimi Çahşmalar Dergisi, Vol. 16 No. 2, pp. 775-797, doi: 10.17263/ jlls.759300.

Ashwin, P. and Mcvitty, D. (2015), "The meanings of student engagement: implications for policies and practices", in Uraj, A.S.P., Matei, L., Pricopie, R. and Salmi, J. (Eds), The European Higher Education Area, Vol. 35, Springer, Cham, pp. 343-359, doi: 10.2753/eue1056-493435029.

Baker, A. (2009), Tree or Three: an Elementary Pronunciation Course, 2nd ed., Cambridge University Press.

Bakla, A. (2018), "Learner-generated materials in a flipped pronunciation class: a sequential explanatory mixed-methods study", Computers and Education, Vol. 125, pp. 1-11, doi: 10.1016/j. compedu.2018.05.017

Basal, A. (2015), "The implementation of a flipped classroom in foreign language teaching", Turkish Online Journal of Distance Education, pp. 28-37, available at: https://dergipark.org.tr/download/ article-file/156695.

Bin-Hady, W.R.A. (2016a), Communicative Competence in Teaching English at Secondary Schools: A Critical Investigation in Yaff'ae District of Yemen, GRIN Verlag.

Bin-Hady, W.R.A. (2016b), "Communicative competence training: a comparison between teachers' focuses and students' feedback”, LangLit, Vol. 3 No. 1, pp. 9-25.

EFL students' achievement and attitudes

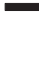


PRR

6,3

Bin-Hady, W.R.A. (2016c), “Teaching pronunciation for Arab learners of English: using Gilberts' prosody pyramid", South-Asian Journal of Multidisciplinary Studies (SAJMS), Vol. 3 No. 3, pp. 138-151.

Choe, E. and Seong, M.H. (2016), "A case study of the flipped classroom in a Korean university general English course”, Journal of Pan-Pacific Association of Applied Linguistics, Vol. 20 No. 2, pp. 71-93, available at: https://files.eric.ed.gov/fulltext/EJ1129484.pdf

Creswell, J.W. (2012), Educational Research: planning, Conducting, and Evaluating Quantitative and Qualitative Research, 4th ed., Pearson Education, Boston.

Doman, E. (2017), "Flipped learning: does it work? TESOL connections. TESOL international association", available at: $\mathrm{http}: /$ newsmanager.commpartners.com/tesolc/issues/2017-10-01/2.html

Jalabneh, A.M. (2014), "The role of interference, prominence, and theory of distinctive features in detecting wrong pronunciations of consonants: a case study of Arab learners of English", available at: www.researchgate.net/profile/Atef_Jalabneh/publication/283896025

Jurmey, P., Lham, T., Lhaden, K., Pema, T. and Rai, B.B. (2019), "Flipped classroom: prospect in freeing up classroom instructional hours, and students' attitude towards flipped classroom strategy", available at: www.researchgate.net/publication/332037024

Karimi, M. and Hamzavi, R. (2017), "The effect of flipped model of instruction on EFL learners' reading comprehension: learners' attitudes in focus", Advances in Language and Literary Studies, Vol. 8 No. 1, pp. 95-103, doi: 10.7575/ aiac.alls.v.8n.1p.95.

Köroğlu, Z.Ç. and Çakır, A. (2017), "Implementation of flipped instruction in language classrooms: an alternative way to develop speaking skills of pre-service English language teachers", International Journal of Education and Development Using Information and Communication Technology (IJEDICT), Vol. 13 No. 2, pp. 42-55.

Maharani, A., Hamamah, H. and Nurhayani, I. (2020), "Indonesian undergraduate EFL students' perceptions toward flipped classroom”, Edcomtech Jurnal Kajian Teknologi Pendidikan, Vol. 5 No. 1, pp. 1-10, doi: 10.17977/um039v5i12020p001.

Obari, H. and Lambacher, S. (2015), "Successful EFL teaching using mobile technologies in a flipped classroom", in Helm, S.T.F., Bradley, L. and Guarda, M. (Eds), Critical CALL - Proceedings of the 2015 EUROCALL Conference, Research-publishing, Padova, Dublin, pp. 433-438.

Singay (2020a), "An investigation into using kagan cooperative learning model to enhance English oral communication ability of Bhutanese students", Pasaa, Vol. 59 No. March, pp. 20-47.

Singay (2020b), "Flipped learning in English as a second language classroom: Bhutanese students' perceptions and attitudes of flipped learning approach in learning grammar", Indonesian Journal of Applied Linguistics, Vol. 9 No. 3, pp. 666-674, doi: 10.17509/ijal.v9i3.2321.

Soler, M., Bentabol, M., Lopes, A.P. and Bentabol, A. (2018), "Looking for students' enthusiasm: flipped classroom, (November)", 11th Annual International Conference of Education, Research and Innovation, doi: 10.21125/ iceri.2018.1209.

Vaezi, R., Afghari, A. and Lotfi, A. (2019), "Investigating listening comprehension through flipped classroom approach: does authenticity matter?", CALL-EJ, Vol. 20 No. 1, pp. 178-208, available at: www.callej.org/journal/20-1/Vaezi-Afghari-Lotfi2019.pdf

Van Alten, D.C.D., Phielix, C., Janssen, J. and Kester, L. (2019), "Effects of flipping the classroom on learning outcomes and satisfaction: a meta-analysis", Educational Research Review, Vol. 28, p. 100281, doi: 10.1016/j.edurev.2019.05.003.

Webb, M. and Doman, E. (2016), "Does the flipped classroom lead to increased gains on learning outcomes in ESL/EFL contexts?”, The CATESOL Journal, Vol. 28 No. 1, pp. 39-67.

Yang, C.C.R. and Chen, Y. (2020), "Implementing the flipped classroom approach in primary English classrooms in China", Education and Information Technologies, Vol. 25 No. 2, pp. 1217-1235.

Yousefzadeh, M. and Salimi, A. (2015), "The effect of flipped learning (revised learning) on Iranian students' learning outcomes", Advances in Language and Literary Studies, Vol. 6 No. 5, doi: 10.7575/aiac.alls.v.6n.5p.209. 
Zainuddin, Z., Haruna, H., Li, X., Zhang, Y. and Chu, S.K.W. (2019), “A systematic review of flipped classroom empirical evidence from different fields: what are the gaps and future trends?”, On the Horizon, Vol. 27 No. 2, pp. 72-86, doi: 10.1108/OTH-09-2018-0027.

Zhang, H., Du, X., Yuan, X. and Zhang, L. (2016), "The effectiveness of the flipped classroom mode on the english pronunciation course", Creative Education, Vol. 7 No. 9, pp. 1340-1346.

\section{Further readings}

Bin-Hady, W.R.A. (2018), "A study of novice teachers' challenges at their practical teaching phase", IJLRES - International Journal on Language, Research and Education Studies, Vol. 2 No. 3, pp. 333-345, doi: 10.30575/2017/IJLRES-2018091203.

Dixon, D.H. (2018), "Use of technology in teaching pronunciation skills", The TESOL Encyclopedia of English Language Teaching, pp. 1-7, doi: 10.1002/9781118784235.eelt0692.

Nunan, D. (2015), Teaching English to Speakers of Other Languages, Routledge.

Webb, M. and Doman, E. (2019), "Impacts of flipped classrooms on learner attitudes towards technology-enhanced language learning", Computer Assisted Language Learning, Vol. 33 No. 3, pp. 240-274, doi: 10.1080/09588221.2018.1557692.

Xin-Yue, Z. (2016), "Motivation in a flipped classroom, a case study of teaching oral English in a vocational college in Mainland China”, Sino-US English Teaching, Vol. 13 No. 6, pp. 460-467, doi: 10.17265/1539-8072/2016.06.004. 


\section{Appendix 1. Questionnaire}

6,3

188

\section{Dear student}

We are working on a research project. Please assist us by providing the most accurate and honest answers to the questions. All information which you provide in this form will be kept confidential and will only be used for research purposes.

\begin{tabular}{|c|c|c|}
\hline Your name: & Your age: & Are you: \\
\hline & & male $/$ female \\
\hline
\end{tabular}
Please look at each of the following statements about flipped class. Circle your level of
agreement.
$1=$ strongly disagree; 5= strongly agree

\begin{tabular}{ll}
\hline No & \multicolumn{1}{c}{ Statement } \\
\hline 1 & I have used flipped class strategy to enhance my pronunciation \\
\hline 2 & $\begin{array}{l}\text { I could learn more about the English sounds if I have the pre-concept before class } \\
\text { learning }\end{array}$ \\
\hline 3 & I have had meaningful learning during the instructional hours \\
\hline 4 & $\begin{array}{l}\text { The videos, recordings, and reading notes about the English sounds before the real } \\
\text { class instructional learning could promote my understanding of the sounds }\end{array}$ \\
\hline 5 & $\begin{array}{l}\text { The videos, recordings, and reading notes beforehand have engaged me in } \\
\text { meaningful class learning }\end{array}$ \\
\hline 6 & The videos and recordings have let me repeat them as long as I need. \\
\hline 7 & $\begin{array}{l}\text { The videos and recordings about the sounds have helped me to see the native } \\
\text { speakers' positions of articulation and imitate them }\end{array}$ \\
\hline 8 & $\begin{array}{l}\text { Recalling the sounds from the videoes and recordings has enabled me to participate } \\
\text { in the class }\end{array}$ \\
\hline 9 & The flipped class learning has become more interactive \\
\hline 10 & The flipped class has made my class learning easier \\
\hline 11 & I could participate more than the usual participation \\
\hline 12 & $\begin{array}{l}\text { Sharing ideas (pre concepts from the video clips, records, and notes) has helped me } \\
\text { understand the English sounds better }\end{array}$ \\
\hline 13 & The greater discussion and interaction in the class has motivated me \\
\hline 14 & Applying flipped learning has enhanced my course outcomes \\
\hline 16 & I also would like to participate in similar classes in the future \\
\hline 17 & I prefer the traditional method to learn pronunciations over flipped class \\
\hline
\end{tabular}




\section{Appendix 2. Structured interview}

\section{Introductory statement}

Thank you for your approval to conduct this semi-structured interview. The purpose of the project is to determine your attitudes towards the flipped pronunciation class. I am going to ask you some questions to get your opinion about the class. This interview will be used for this research project only and is completely unrelated to any other purpose. With your permission, I will record all of our interviews (using an $m p 3$ recorder) to ensure accuracy in recording your responses. Please answer the questions as completely and as honestly as you can.

1) Have you ever studied the sounds before coming to university?

2) What is your opinion about the flipped pronunciation classroom?

3) Do you get enough time to practice pronunciation or not?

4) How do you feel when coming to the lecture prepared?

5) Do you understand better this teaching method or do you want to study by traditional learning?

6) Do you have enough time to practice English with your colleague in the flipped classroom?

7) Do you want to study other courses in the same way as pronunciation?

8) Where did you feel you learned more about pronunciation? In a class or from the videos and recordings

9) In your opinion, what are the strength and weaknesses of flipped classrooms?

\section{Corresponding author}

Abduljalil Nasr Hazaea can be contacted at: agaleel@gmail.com

For instructions on how to order reprints of this article, please visit our website: 